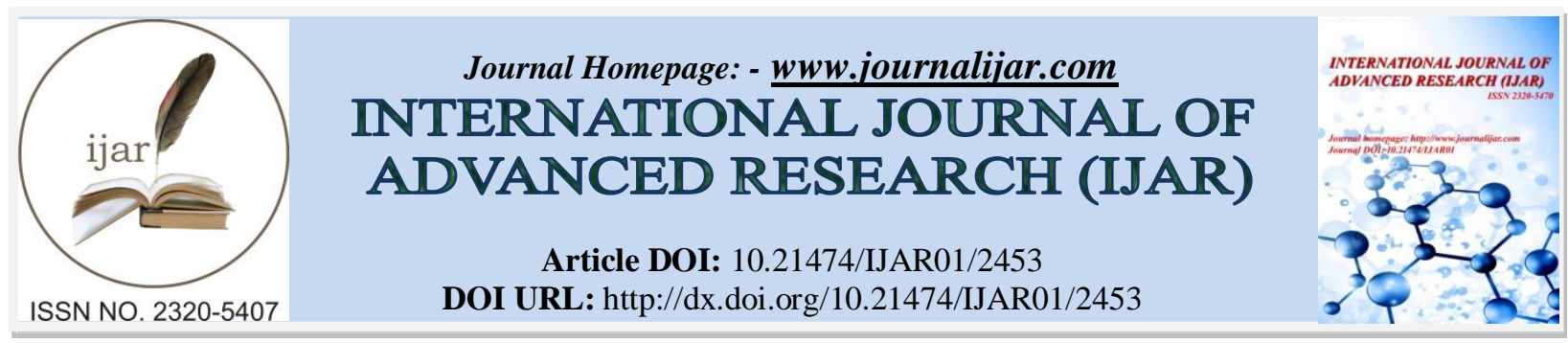

RESEARCH ARTICLE

\title{
A COMPARATIVE STUDY REGARDING AWARENESS OF SEXUALLY TRANSMITTED DISEASES (STD) AMONG ADOLESCENT GIRLS IN SELECTED AREAS OF UP \& UTTARAKHAND.
}

Mansha Mani Tripathi ${ }^{1}$ and Prof. Arun Bahuguna ${ }^{2}$.

1. Research Scholar, Extension Education, HNB Garhwal Central University, Srinagar Garhwal, Uttarakhand.

2. Professor, DACEE, HNB Garhwal Central University, Srinagar Garhwal, Uttarakhand.

\section{Manuscript Info}

Manuscript History

Received: 20 October 2016

Final Accepted: 22 November 2016

Published: December 2016

Key words:-

Adolescents, Awareness, Sexually

Transmitted Diseases, Knowledge.

\section{Abstract}

This study was conducted to investigate the adolescents' awareness of sexually transmitted diseases, including their level of knowledge regarding the mode of transmission and prevention of sexually transmitted diseases. The study was performed using a self structured questionnaire which was distributed to the selected sample size eliciting information about the knowledge of sexually transmitted diseases. 100 adolescents (50 from Srinagar city (urban) and 50 from countryside area of district Gorakhpur) were randomly selected amongst urban and rural adolescent girls aged 12-18. The study revealed that the adolescent girls of rural area of district Gorakhpur (UP) lacked awareness of sexually transmitted diseases, and they have incorrect perceptions about the statements asked.

Copy Right, IJAR, 2016,. All rights reserved.

\section{Introduction:-}

The stage of life during which individuals reach sexual maturity is known as adolescence. It is the period of transition from childhood to adulthood. Although the change is biological, the duration and nature of adolescence are primarily a social construct and thus vary from culture to culture. World Health Organization (WHO) identifies the age range 10-19 years as the period of adolescence, while the term "youth" denotes the age group 15-24. At present time, awareness towards health is necessary to improve the standard of life and maintain quality of life. Over-growth of population would affect the health dimension so it is necessary to increase the level of information towards health care; especially women need to pay more attention to it. Girls in the family need to be aware of their health so that sexually transmitted diseases can be prevented. Adolescence is a transition period between childhood and adulthood characterized by an intense period of growth and development that includes outstanding anatomical, physiologic, psychological and social transformations.

Sexually transmitted diseases (STDs) are infectious diseases transmitted through sexual contact. 50\% of new STDs happen in people basically in girls in the age of 15-24 years. Adolescents age 15-24 account for nearly half of the 20 million new cases of STDs each year. Today, 2 in 5 sexually active teen girls have had an STD that cause infertility and even death. Adolescent girls receive limited sexual education. So the result is that 19 million STD are acquired in United States each year, mainly in the 14-29 year old age group.

There are many sexually transmitted diseases (STD) which can infect adolescents (see table 1)

Adolescent girls suffer more frequent and severe symptoms from STDs. 
- Some STDs can spread into the uterus (womb) and fallopian tubes. This can lead to both infertility and ectopic (tubal) pregnancy.

- Some strains of HPV infection in girls may also be associated with cervical cancer.

- STDs can be pushed from a mother to her baby before or during birth. Some infections of the newborn may be successfully treated.

Table 1:-

\begin{tabular}{|l|l|}
\hline Human Papillomavirus & Hepatitis A, B, C \\
\hline Trichomonas Viginalis & Haemophilus Ducreyi (Chancroid) \\
\hline Chlamydia Trachomatis & Pediculosis pubis \\
\hline Neisseria gonorrhoeae & Sarcoptes scabiei \\
\hline Herpes simplex virus (HPV) & Gardnerella Vaginalis \\
\hline HIV (Human Immunodeficiency Virus) & Sexually associated \\
\hline Treponema Pallidum (Syphilis) & Lymphogranuloma Venereum (LGV) \\
\hline
\end{tabular}

\section{Material \& Methods:-}

The objective of the study is to find out the level of awareness of Sexually Transmitted Diseases (STD) among Adolescents girls of rural and urban areas. Sample consist of 100 adolescents girls (50 urban \& 50 rural). Sample of 50 rural adolescent girls of Gorakhpur district, U.P. and 50 urban adolescent girls of Srinagar Garhwal, Uttarakhand were selected. For the present study, a self prepared tool is used. A self prepared questionnaire tool has 15 items. Number of awareness and number of unawareness in each item were calculated by percentage method. Statistical Technique of percentage is used in the Study. This comparative study is delimited to urban area Govt. Girls Inter College, Srinagar Garhwal, Uttarakhand and rural area of Gorakhpur district of Uttar Pradesh.

\section{Result and Discussion:-}

The study the knowledge of Sexually Transmitted Diseases (STD) among Adolescent girls of rural and urban areas is tabulated below:

Table 1.1:- Focuses on personal hygiene in daily life?

\begin{tabular}{|l|l|l|l|l|l|l|}
\hline Study Area & Frequency & \multicolumn{4}{l|}{ Percentage (\%) } \\
\cline { 2 - 7 } & Yes & No & Total & Yes & No & $\%$ \\
\hline Gorakhpur (Rural) & 30 & 20 & 50 & 60 & 40 & 100 \\
\hline Srinagar (Urban) & 38 & 12 & 50 & 80 & 20 & 100 \\
\hline
\end{tabular}

It is shown in above table 1.1 regarding the statement, 'Whether they focus on personal hygiene? the adolescent girls of Srinagar town is greater $(80 \%)$ than that of rural girls $(60 \%)$ of Gorakhpur district.

Table 1.2:- What are the effects of the lack of nutrition in adolescence?

\begin{tabular}{|l|l|l|l|l|l|l|}
\hline Study Area & Frequency & Percentage (\%) \\
\cline { 2 - 7 } & Yes & No & Total & Yes & No & $\%$ \\
\hline Gorakhpur (Rural) & 30 & 20 & 50 & 60 & 40 & 100 \\
\hline Srinagar (Urban) & 40 & 10 & 50 & 90 & 10 & 100 \\
\hline
\end{tabular}

From the above table 1.2, lack of awareness among the girls of Gorakhpur district was found i.e. $60 \%$ whereas the girls residing in urban area were more aware in this regard i.e. $90 \%$ as shown in table.

Table 1.3:- How Sexually transmitted diseases affect HIV?

\begin{tabular}{|l|l|l|l|l|l|l|}
\hline Study Area & Frequency & \multicolumn{5}{l|}{ Percentage (\%) } \\
\cline { 2 - 7 } & Yes & No & Total & Yes & No & $\%$ \\
\hline Gorakhpur (Rural) & 20 & 30 & 50 & 40 & 60 & 100 \\
\hline Srinagar (Urban) & 35 & 15 & 50 & 70 & 30 & 100 \\
\hline
\end{tabular}

According to statement number 3, 'How sexually transmitted diseases affect HIV', it is clearly observed that adolescent girls of urban area were more aware (70\%) than that of rural area (40\%). 
Table 1.4:- What is benefit of not using of contaminated syringes?

\begin{tabular}{|l|l|l|l|l|l|l|}
\hline \multirow{2}{*}{ Study Area } & Frequency & \multicolumn{3}{|l|}{ Percentage (\%) } \\
\cline { 2 - 7 } & Yes & No & Y & Yes & No & \% \\
\hline Gorakhpur (Rural) & 38 & 12 & 50 & 76 & 24 & 100 \\
\hline Srinagar (Urban) & 40 & 10 & 50 & 90 & 10 & 100 \\
\hline
\end{tabular}

The data shown in table 1.4 revealed that $76 \%$ rural girls of Gorakhpur district were aware regarding the statement, 'benefit of not using contaminated syringe' while this percentage in urban girls of Srinagar city is more which is $90 \%$ which clearly shows their high awareness level.

Table 1.5:- Which infection is at risk in the absence of timely treatment of sexually transmitted diseases?

\begin{tabular}{|l|l|l|l|l|l|l|}
\hline \multirow{2}{*}{ Study Area } & Frequency & \multicolumn{3}{l|}{ Percentage (\%) } \\
\cline { 2 - 7 } & Yes & No & \% & Yes & No & \% \\
\hline Gorakhpur (Rural) & 15 & 35 & 50 & 30 & 70 & 100 \\
\hline Srinagar (Urban) & 30 & 20 & 50 & 60 & 40 & 100 \\
\hline
\end{tabular}

On the basis of calculated data as shown in table 1.5, we can say that the $70 \%$ rural girls of Gorakhpur district are lack in awareness level while the same percentage is much different in urban girls of Srinagar city which is $40 \%$ only.

Table 1.6:- How progression of anemia can be prevented?

\begin{tabular}{|l|l|l|l|l|l|l|}
\hline \multirow{2}{*}{ Study Area } & Frequency & \multicolumn{4}{|l|}{ Percentage (\%) } \\
\cline { 2 - 7 } & Yes & No & Y & Yes & No & \% \\
\hline Gorakhpur (Rural) & 20 & 30 & 50 & 40 & 60 & 100 \\
\hline Srinagar (Urban) & 30 & 20 & 50 & 60 & 40 & 100 \\
\hline
\end{tabular}

It is shown in above table 1.6 regarding the statement, 'How progression of anemia can be prevented? the adolescent girls of Srinagar town is greater $(60 \%)$ than that of rural girls $(40 \%)$ of Gorakhpur district.

Table 1.7:- Whether consult to doctor having UTI?

\begin{tabular}{|l|l|l|l|l|l|l|}
\hline Study Area & Frequency & \multicolumn{5}{l|}{ Percentage (\%) } \\
\cline { 2 - 7 } & Yes & No & \% & Yes & No & \% \\
\hline Gorakhpur (Rural) & 15 & 35 & 50 & 30 & 70 & 100 \\
\hline Srinagar (Urban) & 30 & 20 & 50 & 60 & 40 & 100 \\
\hline
\end{tabular}

According to statement number 7, 'whether consult to doctor suffering from UTI' the awareness of rural adolescent girls of Gorakhpur is $30 \%$ while the awareness level in the adolescents girls of Srinagar city is high i.e. $60 \%$.

Table 1.8:- What are the symptoms of sexually transmitted diseases?

\begin{tabular}{|l|l|l|l|l|l|l|}
\hline Study Area & Frequency & Percentage (\%) \\
\cline { 2 - 7 } & Yes & No & \% & Yes & No & \% \\
\hline Gorakhpur (Rural) & 25 & 25 & 50 & 50 & 50 & 100 \\
\hline Srinagar (Urban) & 35 & 15 & 50 & 70 & 30 & 100 \\
\hline
\end{tabular}

From the above table 1.8, lack of awareness among the girls of Gorakhpur district was found i.e. 50\% whereas the girls residing in urban area were more aware in this regard i.e. $70 \%$ as shown in table.

Table 1.9:- Whether consult to the doctor in more bleeding during menstruation?

\begin{tabular}{|l|l|l|l|l|l|l|}
\hline Study Area & Frequency & \multicolumn{5}{l|}{ Percentage (\%) } \\
\cline { 2 - 7 } & Yes & No & \% & Yes & No & \% \\
\hline Gorakhpur (Rural) & 30 & 20 & 50 & 60 & 40 & 100 \\
\hline Srinagar (Urban) & 40 & 10 & 50 & 90 & 10 & 100 \\
\hline
\end{tabular}

In the above statement data revealed that $60 \%$ rural girls of Gorakhpur district were aware about the statement, 'consult to the doctor in more bleeding during menstruation' while this percentage in urban girls of Srinagar city is more which is $90 \%$ which clearly shows their awareness level. 
Table 1.10:- What are the causes of malnutrition in adolescence?

\begin{tabular}{|l|l|l|l|l|l|l|}
\hline \multirow{2}{*}{ Study Area } & Frequency & \multicolumn{4}{|l|}{ Percentage (\%) } \\
\cline { 2 - 7 } & Yes & No & \% & Yes & No & \% \\
\hline Gorakhpur (Rural) & 28 & 22 & 50 & 56 & 44 & 100 \\
\hline Srinagar (Urban) & 35 & 15 & 50 & 70 & 30 & 100 \\
\hline
\end{tabular}

The above table shows that rural girls of Gorkahpur district are lacked (56\%) in the statement 'causes of malnutrition' in comparison of urban girls of Srinagar city which is $70 \%$.

Table 1.11:- What is the risk of incomplete treatment of sexually transmitted disease?

\begin{tabular}{|l|l|l|l|l|l|l|}
\hline Study Area & Frequency & Percentage (\%) \\
\cline { 2 - 7 } & Yes & No & \% & Yes & No & \% \\
\hline Gorakhpur (Rural) & 20 & 30 & 50 & 40 & 60 & 100 \\
\hline Srinagar (Urban) & 35 & 15 & 50 & 70 & 30 & 100 \\
\hline
\end{tabular}

By analyzing the data given in table 1.11, it is observed that urban girls of Srinagar city were more aware regarding the statement 'risk of incomplete treatment of STD' which is $70 \%$ while this percentage is rural girls of Gorakhpur district is low $(40 \%)$.

Table 1.12:- Whether discuss to your mother having sexually transmitted disease?

\begin{tabular}{|l|l|l|l|l|l|l|}
\hline Study Area & Frequency & \multicolumn{4}{l|}{ Percentage (\%) } \\
\cline { 2 - 7 } & Yes & No & \% & Yes & No & \% \\
\hline Gorakhpur (Rural) & 22 & 28 & 50 & 44 & 56 & 100 \\
\hline Srinagar (Urban) & 30 & 20 & 50 & 60 & 40 & 100 \\
\hline
\end{tabular}

In the above statement data revealed that only $44 \%$ rural girls of Gorakhpur district were aware regarding the statement, 'Whether discuss to their mother having suffering from sexually transmitted disease' while the awareness level among urban girls of Srinagar city in this regard is $60 \%$ which clearly shows their high awareness level.

Table 1.13:- Whether consult to the doctor in bleeding rather than menstruation period?

\begin{tabular}{|l|l|l|l|l|l|l|}
\hline Study Area & Frequency & Percentage (\%) \\
\cline { 2 - 7 } & Yes & No & \% & Yes & No & \% \\
\hline Gorakhpur (Rural) & 30 & 20 & 50 & 60 & 40 & 100 \\
\hline Srinagar (Urban) & 40 & 10 & 50 & 90 & 10 & 100 \\
\hline
\end{tabular}

On the basis of calculated data as shown in table 1.13, we can say that the rural girls of Gorakhpur district are lack in awareness level, which is $60 \%$ while the same percentage is much different in urban girls Srinagar city which is $10 \%$ only.

Table 1.14:- Whether consult to the doctor during Dysuria?

\begin{tabular}{|l|l|l|l|l|l|l|}
\hline Study Area & Frequency & \multicolumn{4}{l|}{ Percentage (\%) } \\
\cline { 2 - 7 } & Yes & No & \% & Yes & No & \% \\
\hline Gorakhpur (Rural) & 25 & 25 & 50 & 50 & 50 & 100 \\
\hline Srinagar (Urban) & 35 & 15 & 50 & 70 & 30 & 100 \\
\hline
\end{tabular}

Data shown in the table 1.14 shows that the awareness of adolescent girls of Srinagar city is more (70\%) than the rural girls of Gorakhpur which is $50 \%$.

Table 1.15:- What are the symptoms of impetus behaviour in adolescent?

\begin{tabular}{|l|l|l|l|l|l|l|}
\hline Study Area & Frequency & \multicolumn{5}{l|}{ Percentage (\%) } \\
\cline { 2 - 7 } & Yes & No & \% & Yes & No & \% \\
\hline Gorakhpur (Rural) & 20 & 30 & 50 & 40 & 60 & 100 \\
\hline Srinagar (Urban) & 35 & 15 & 50 & 70 & 30 & 100 \\
\hline
\end{tabular}

According to statement number 15 'symptoms of impetus behaviour' the awareness of rural adolescent girls of Gorakhpur is $40 \%$ while the awareness in the adolescent girls of Srinagar city which is $70 \%$. 


\section{Conclusion:-}

1. Awareness regarding personal hygiene in most urban teenagers has been found while it is relatively low in rural girls due to lack of health consciousness in them.

2. Most urban adolescents have the knowledge regarding the statement, 'effect on adolescent due to lack of nutrition' while illiteracy throw rural girls back as they hold the least awareness as revealed from the data.

3. Urban adolescent girls regarding the statements, 'symptoms of STD, risk of infection due to incomplete treatment and STD affect HIV, were more aware than that of rural adolescent girls. Social contact; social mobility and higher education level are the root cause of unawareness in rural girls.

4. Generally, all urban adolescent girls discusses with their mothers having sexually transmitted disease but awareness level was found low in rural girls in this regard due to their social environment and traditional practices.

5. Urban adolescents were more aware regarding benefit from not using contaminated syringes and consultation with doctor during bleeding in other than menstruation cycle days while it is low in rural adolescent girls due to lack of constant communication and not being sensitive towards their own health.

\section{Suggestions:-}

Based on the findings of the present study, the suggestions in this regard are as follows:

1. A study related to attitude levels towards Sexually transmitted diseases in adolescents is required to perform.

2. Health-related awareness study in Adolescent girls of rural areas is needed to explore.

3. H.I.V. and AIDS related awareness programs are required to perform.

4. The role of Government and Non-Government organizations/institutions should be ensured to increase awareness regarding nutrition in rural areas.

\section{References:-}

1. Mbah CJ. (2003). Sexual behavior and the risks of HIV/AIDS and other STDs among young people in SubSaharan Africa: A review. Research Review NS 19.1: 15-25.

2. Berlan, ED and Holland,-Hall, C (2010). Sexually transmitted infections in adolescents: advances in epidemiology, screening and diagnosis. Adolescent Medicine: State of Art Reviews, 21, 332-46, x.

3. Johnson, J. Sexually transmitted diseases in adolescents. In: Greydanus, DE, Patel, DR, Pratt, HD (eds.) Essential Adolescent Medicine, NY: McGraw-Hil Medical Publishers, 2006, p. 805.

4. Centres for Disease control and prevention (CDC). Guidelines for treatment of sexually transmitted diseases. Morb Mort Week Rep 2006: 55(RR-11): 1-94.

5. Agarwal, S.N. Population Problem of less developed countries, Tata McGraw-Hill publication pvt. Ltd.

6. Johnson, J. Sexually transmitted diseases in adolescents. ([chapter 24])in: D.E. Greydanus, D.R. Patel, H.D. Pratt (Eds.) Essentials of adolescent medicine. McGraw-Hill Medical Publishers, New York; 2006:511-542. 